\title{
Sistem Pendukung Keputusan Penentuan Uang Kuliah Tunggal Universitas XYZ Menggunakan Algoritma Backpropagation
}

\author{
Raden Muihamad Firzatullah ${ }^{1}$; Andi Nurkholis ${ }^{2}$; Albar Rubhasy ${ }^{3}$; Riad Shara ${ }^{4}$ \\ ${ }^{1}$ Raden Muhamad Firzatullah 1 Universitas Nasional \\ ${ }^{2}$ Andi Nurkholis 2 Universitas Teknokrat Indonesia \\ ${ }^{3}$ Albar Rubhasy 3 Universitas Nasional \\ ${ }^{4}$ Riad Shara 4 Universitas Nasional \\ ${ }^{1}$ firzatullah@ civitas.unas.ac.id
}

\begin{abstract}
The determination of the student's single tuition fee grade at XYZ University still faces problems, one of which is the inconsistency of supporting variables which change each year based on the number of students and the level of student welfare. Determination of the class of student's single tuition fee based on the web that applies the backpropagation algorithm is designed to produce an adaptive decision-making system for changing variable determinants so that every year it is not necessary to adjust the weight in determining the student's single tuition fee group. In building a decision support system to determine the student's single tuition fee group, there are several stages including data collection, data processing, backpropagation implementation, evaluation and presentation of the model, and implementation of a web-based decision support system. During the evaluation and presentation of the model, several experiments were carried out by considering various parameters to get the best accuracy results. The accuracy of the best model produced in this study reached $86 \%$ with output in the form of a web-based decision support system that is ready to be managed by the Center for Information and Computer Technology (PUSTIKOM) of XYZ University for use by new students.
\end{abstract}

Keywords: Backpropagation, Multilayer Perceptron, Student's Single Tuition Fee, Decision Support System

\begin{abstract}
ABSTRAK
Penentuan golongan UKT di Universitas XYZ masih menemui permasalahan, salah satunya adalah inkonsistensi variabel-variabel pendukung yang mana berubah-ubah pada setiap tahunnya berdasarkan jumlah dan kemampuan ekonomi mahasiswa yang diterima. Penentuan golongan UKT berbasis web menggunakan metode multilayer perceptron dengan tipe backpropagation dirancang bertujuan dapat menjadi sistem model yang adaptif terhadap perubahan jumlah serta kemampuan ekonomi mahasiswa dan juga perubahan variabel penentu UKT, sehingga pada setiap tahunnya tidak perlu dilakukan lagi melakukan penyesuaian bobot dalam penentuan golongan UKT. Dalam membangun sistem pendukung keputusan penentuan golongan UKT, terdapat beberapa tahapan yang dilalui yaitu, pengumpulan data, praproses data, implementasi backpropagation, evaluasi dan presentasi model, dan implementasi sistem pendukung keputusan berbasis web. Pada tahap evaluasi dan presentasi model dilakukan beberapa eksperimen dengan mempertimbangkan berbagai parameter untuk mendapatkan hasil akurasi terbaik. Akurasi model terbaik yang dihasilkan pada penelitian ini mencapai $86 \%$ dengan output berupa sistem pendukung keputusan berbasis web yang siap dikelola oleh Pusat Teknologi Informasi dan Komputer (PUSTIKOM) Universitas XYZ untuk digunakan oleh mahasiswa baru.
\end{abstract}

Kata kunci: Backpropagation, Multilayer Perceptron, Uang Kuliah Tunggal, Sistem Pengambilan Keputusan 


\section{PENDAHULUAN}

Uang kuliah tunggal merupakan biaya pendidikan mahasiswa selama satu semester yang sudah mendapat pengurangan biaya melalui subsidi pemerintah dan tidak ada lagi pungutan diluar biaya UKT. Tujuan dari penerapan sistem UKT adalah untuk lebih membantu dan meringankan biaya pendidikan mahasiswa dengan sistem subsidi silang melalui penggolongan UKT. Penetapan uang kuliah tunggal memberikan kemudahan untuk memprediksi pengeluaran biaya kuliah mahasiswa tiap semester dan dipastikan tidak ada biaya tambahan lain-lain lagi. Sesuai dengan amanah konstitusi permendikbud no. 55 tahun 2013 yaitu kebijakan UKT diberikan kepada lembaga pendidikan Negeri dengan perhitungan dana sesuai dengan kondisi ekonomi mahasiswa. Dana dimaksud dibayarkan persemester oleh mahasiswa dan ada penggolangan UKT yang disesuaikan dengan kondisi ekonomi mahasiswa, dengan kata lain bahwa kelangsungan pendidikan tersebut bermakna bahwa ada subsidi silang antar mahasiswa, dalam penyelenggaraan pendidikan oleh perguruan tinggi dan mahasiswa tidak dipungut biaya lain selain biaya UKT, artinya tidak ada uang gedung dan SPI yang harus dibayar oleh mahasiswa [1].

Pada implementasinya, kebijakan UKT masih memunculkan masalah pada beberapa perguruan tinggi negeri, salah satunya di Universitas XYZ. Di Universitas XYZ, kebijakan penentuan UKT berubah-ubah pada setiap tahunnya berdasarkan jumlah dan kemampuan ekonomi mahasiswa yang diterima yang mana hal tersebut mengacu pada peraturan permenristekdikti no. 22 tahun 2015 bahwasanya jumlah mahasiswa pada golongan 1 dan 2 paling sedikit adalah $10 \%$ dari total keseluruhan yang diterima. Sedangkan pada setiap tahunnya, mahasiswa yang layak ditempatkan di golongan 1 dan 2 berdasarkan kemampuan ekonominya berubah-ubah. Selain itu, variabel dalam penentuan UKT juga dipengaruhi oleh nilai rupiah pada saat itu. Sebagai contoh, tarif listrik pada tahun 2015 berbeda dengan tarif listrik pada tahun 2016, begitu juga dengan variabelvariabel lainnya. Kebijakan dalam pengambilan keputusan penentuan bobot variabel UKT dilakukan oleh petinggi Universitas XYZ mengikuti kebijakan kementerian Pendidikan tinggi dan parameter lain. Pada prosesnya sering terjadi perbedaan pendapat dan mengakibatkan penentuan kebijakan memakan proses yang lama. Selain itu, proses penentuan UKT sendiri di Universitas XYZ melalui beberapa proses diantaranya pengisian form informasi tanggungan dan pemasukan keluarga, proses verifikasi oleh panitia hingga survey ke lokasi tempat tinggal calon mahasiswa baru yang dilakukan oleh panitia. Hal tersebut memerlukan waktu dan biaya tambahan, ditambah kondisi pandemi covid19 pun mengakibatkan beberapa proses tidak dapat dilaksanakan secara konvensional. Maka diperlukan suatu Sistem Sistem Informasi yang dapat melakukan penentuan UKT secara adaptif seiring dengan perubahan kebijakan dalam penentuan bobot variabel penentu UKT dan sistem yang meminimalisir kontak langsung. Proses penentuan UKT di Universitas XYZ sudah berlangsung selama 4 tahun, dimana setiap tahunnya terdapat \pm 5.000 data calon mahasiswa baru. Data yang telah diproses pada tahun sebelumnya dapat digunakan untuk data pembelajaran Sistem Informasi penentuan UKT. Sistem Pengambilan Keputusan merupakan sistem informasi interaktif yang berfungsi untuk membantu manajemen dalam mengambil keputusan dengan menggunakan pemodelan data atau peralatan data analisis sebagai dasar pengembangan alternatif yang dapat digunakan oleh pemakai [2]. Sistem Pengambilan Keputusan ssudah digunakan dalam beberapa penelitian dalam mengambil kebijakan serta menfasir harga diantaranya penelitian yang dilakukan oleh [3] dan [4]. Maka pada penelitian ini kami akan mengembangkan sistem informasi yang menerapkan Sistem Pengambilan Keputusan dalam penentuan biaya UKT.

Neural Network merupakan suatu metode supervised-learning, dimana model memerlukan dataset yang telah diberi pelebelan dari proses yang sudah rampung[5]. Selain itu Neural Network sudah digunakan dalam beberapa penelitian dalam penentuan harga dan kebijakan diantaranya 
[6],[7],[8],[9],[10]. Hal tersebut mendorong kami untuk menerapkan Neural Network sebagai model dalam penentuan UKT. Multi-layer Perceptron muerpakan kelas dari jaringan syaraf tiruan, dimana MLP memiliki layer yang lebih banyak dibandingkan dengan single layer perceptron, dimana MLP setidaknya memiliki tiga layer diantaranya layer input, layer proses dan layer output [11]. MLP memiliki akurasi yang lebih tinggi dibandingkan dengan SLP seperti yang ditunjukan pada penelitian [12],[13]. Terdapat teknik pemebelajaran yang diawasi, dimana proses pembelajaran berlangsung secara berulang dengan propagasi mundur yang dinamakan backpropagation. Backpropagation merupakan salah satu bagian dari Neural Network. Backpropagation merupakan metode pelatihan terawasi (supervised learning), dalam artian mempunyai target yang akan dicari [14]. Model backpropagation memiliki keunggulan tingkat akurasi dibandingkan dengan metode single-layer perceptron awal seperti yang ditunjukan pada penelitian [15] dan [16]. Berdasarkan hal tersebut, maka dalam penelitian ini kami akan menggunakan metode backpropagation dalam pengembangan model Sistem Pengambilan Keputusan untuk menentukan biaya UKT yang selanjutnya diimplementasikan pada Sistem Informasi terkait.

\section{METODE/PERANCANGAN PENELITIAN}

Tahapan yang dilakukan pada penelitian ini dapat diilustrasikan pada Gambar 1.

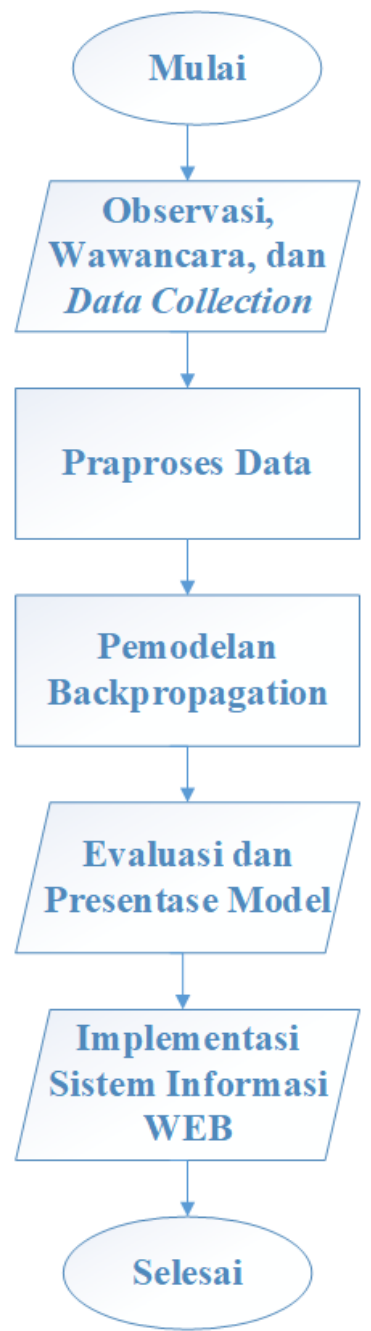

Gambar 1. Metodologi penelitian 


\subsection{Pengumpulan Data}

Pada penelitian ini dilakukan pengumpulan data dengan pengambilalihan data histori yang telah ada sebelumnya sebanyak 9.822 record. Tahap selanjutnya adalah wawancara terhadap pakar untuk menentukan variabel-variabel utama yang digunakan dalam penentuan golongan uang kuliah tunggal. Variabel-variabel yang telah disetujui oleh pakar adalah 12 variabel dengan rincian 11 variabel berupa faktor dan 1 variabel sebagai kelas target (golongan UKT).

\subsection{Praproses Data}

Praproses yang dilakukan pada penelitian ini berupa penanganan missing value dengan metode rata-rata, seleksi data berdasarkan wawancara yang dilakukan kepada pakar untuk meminimalkan variabel-variabel yang digunakan dengan hasil 5 variabel. 5 variabel tersebut merupakan gabungan dari 11 variabel diantaranya:

- v1-penghasilan terdiri dari penghasilan ibu, penghasilan ayah, kesanggupan wali, penghasilan pribadi, dan tanggungan

- v2-biaya tempat tinggal terdiri dari pajak bumi bangunan, jumlah kepala keluarga, dan biaya kontrak

- v3-tagihan listrik

- v4-pajak motor

- v5-pajak mobil

Pada penelitian ini juga dilakukan metode sampling dengan hanya menggunakan 800 record dari 9.822 record dengan syarat setiap target klasifikasi memiliki 100 record. Hal ini dilakukan untuk meminimalkan waktu proses pembentukan model.

\subsection{Implementasi Backpropagation [11 pts/Bold]}

Pada tahap ini dilakukan inisialisasi node input, node hidden layer, dan node output dengan berbagai percobaan. Dimana detail dari inisialisasi atribut backpropagation yang digunakan tertera pada tabel 1 .

Tabel 1. Inisialisasi Atribut Backpopagation

\begin{tabular}{|l|l|}
\hline \multicolumn{1}{|c|}{ Atribut } & \multicolumn{1}{c|}{ Nilai Insialisasi Atribut } \\
\hline Learning rate & $0.1,0.25,0.5,0.75$ \\
\hline Jumlah Hidden Layer & $1,2,3$ \\
\hline Jumlah Node Hidden Layer & $1(30), 2(30,30), 3(30,30,30)$ \\
\hline
\end{tabular}

Setelah dilakukan inisialisasi, maka dilakukan iterasi dengan propagasi balik hingga kondisi yang ditetapkan terpenuhi. Dimana tahapan backpropagation terdiri dari 2 tahap diantaranya forwardpass dan backward-pass. Dilakukan proses penghitungan hidden layer pada tahap forward-pass dengan rumus sebagai berikut:

$$
\begin{gathered}
\mathrm{H}_{\mathrm{i}}=\sum\left(\mathrm{i}_{\mathrm{i}} \times \mathrm{w}_{\mathrm{i}}\right)+\sum \mathrm{b}_{\mathrm{i}} \\
\text { Out } \mathrm{H}_{\mathrm{i}}=\frac{1}{\left(1+e^{-h 1}\right)} \\
\mathrm{O}_{1}=\Sigma\left(\text { Out } \mathrm{H}_{\mathrm{i}} \times \mathrm{w}_{\mathrm{i}}\right)+\Sigma \mathrm{b}_{\mathrm{i}}
\end{gathered}
$$

Hasil pada tahap ini adalah arsitektur model dengan bobot-bobot pada hidden layer. Selanjutnya dilakukan penghitungan nilai error dengan rumus sebagai berikut:

$$
\mathrm{E}_{\mathrm{i}}=\frac{1}{2}\left(\mathrm{t}_{\mathrm{i}}-\text { out } \mathrm{o}_{\mathrm{i}}\right)^{2}
$$


Dimana (H) merupakan Hidden Layer, (i) meruapakan input, (w) meruapakan weight/beban layer dan (b) meruapakan nilai bias. Setelah dilakukan proses forward-pass, selanjutnya dilakukan proses backward-pass untuk mengupdate nilai bobot dari masing-masing hidden layer menggunakan rumus:

$$
\begin{gathered}
\mathrm{w}_{\text {new }}=\mathrm{w}_{\text {old }}-\alpha \frac{\partial \mathrm{E}}{\partial \mathrm{w}} \\
\mathrm{b}_{\text {new }}=\mathrm{b}_{\text {old }}-\alpha \frac{\partial \mathrm{E}}{\partial \mathrm{b}}
\end{gathered}
$$

Dimana (E) merupakan Error, (w) merupakan weight dan (b) meruapakan bias. Sehingga setelah seluruh bobot dari hidden layer berhasil diperbarui maka model dari backpropagation dapat digunakan. Adapun gambaran proses backpropagation tertera pada Gambar 2.

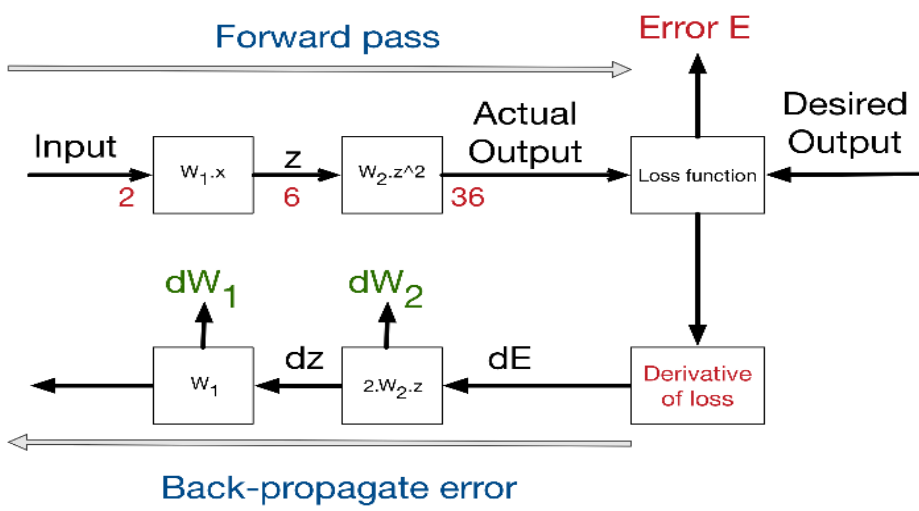

Gambar 2. Proses backpropagation

Pada penelitian ini proses penghitungan backpropagation dilakukan secara berulang untuk mendapatkan hasil akurasi terbaik dengan mempertimbangkan aspek threshold, learning rate, jumlah hidden layer, dan jumlah node pada hidden layer.

\subsection{Evaluasi dan Presentasi Model}

Pada penelitian ini dilakukan beberapa eksperimen dengan mempertimbangkan berbagai parameter untuk mendapatkan hasil akurasi terbaik. Hasil akurasi terbaik dapat dihitung dengan rumus confusion matrix sebagai berikut [17]:

$$
\text { Akurasi }=\frac{T}{n} \times 100 \%
$$

Dimana $\mathrm{T}$ (true) adalah adalah jumlah data yang diprediksi yang berada di kelas yang direkomendasikan dan pada hasilnya mereka berada di kelas yang direkomendasikan, sedangkan $\mathrm{n}$ adalah jumlah keseluruhan data yang digunakan. Dengan memperhatikan parameter-parameter yang mempengaruhi, dilakukan evaluasi terhadap eksperimen-eksperimen yang telah dilakukan, sehingga didapatkan mode dengna akurasi terbaik dalam penentukan golongan uang kuliah tunggal.

\subsection{Implementasi Sistem Informasi Berbasis Website}

Pada tahap ini dilakukan implementasi model terbaik yang telah diperoleh sebelumnya pada platform sistem informasi berbasis web. Sistem yang dibuat bertujuan untuk dapat siap digunakan oleh staff PUSTIKOM Universitas XYZ dalam mempermudah penentuan golongan UKT bagi mahasiswa baru. 


\section{HASIL DAN PEMBAHASAN}

Pada penelitian ini akan dilakukan beberapa evaluasi eksperimental untuk menguji konfigurasi neural network backpropagation terhadap hasil prediksi uang kuliah tunggal. Adapun konfigurasi yang dilakukan untuk menguji tingkat akurasi neural network diantaranya threshold, learning rate, jumlah hidden layer, dan jumlah node pada hidden layer. Sedangkan pada penelitian ini digunakan 9822 data yang telah dinormalisasi sebagai data training, dimana setiap data memiliki class diantaranya class kategori 1 hingga class kategori 8. Selain itu digunakan 800 data yang telah dinormalisasi sebagai data testing, dimana masing-masing class memiliki jumlah data yang sama yakni 100 data pada setiap class. Untuk normalisasi data digunakan rumus normalisasi sebagai berikut [17]:

$$
X^{\prime}=\frac{X-X_{\min }}{X_{\max }-X_{\min }}
$$

Setelah data dinormalisasi, selanjutnya dilakukan pengujian konfigurasi neural network backpropagation untuk menemukan hasil klasifikasi yang memiliki akurasi tinggi.

\subsection{Learning Rate}

Dilakukan pengujian learning rate dengan jumlah hidden layer 2 dimana masing-masing jumlah hidden layer memiliki jumlah node 30 dengan threshold rate 0.5. Dan dilakukan pengujian pada learning rate yang berbeda, diantaranya $0.75,0.5,0.25,0.1$. Hasil perbandingan tersebut dapat dilihat pada Gambar 3 .

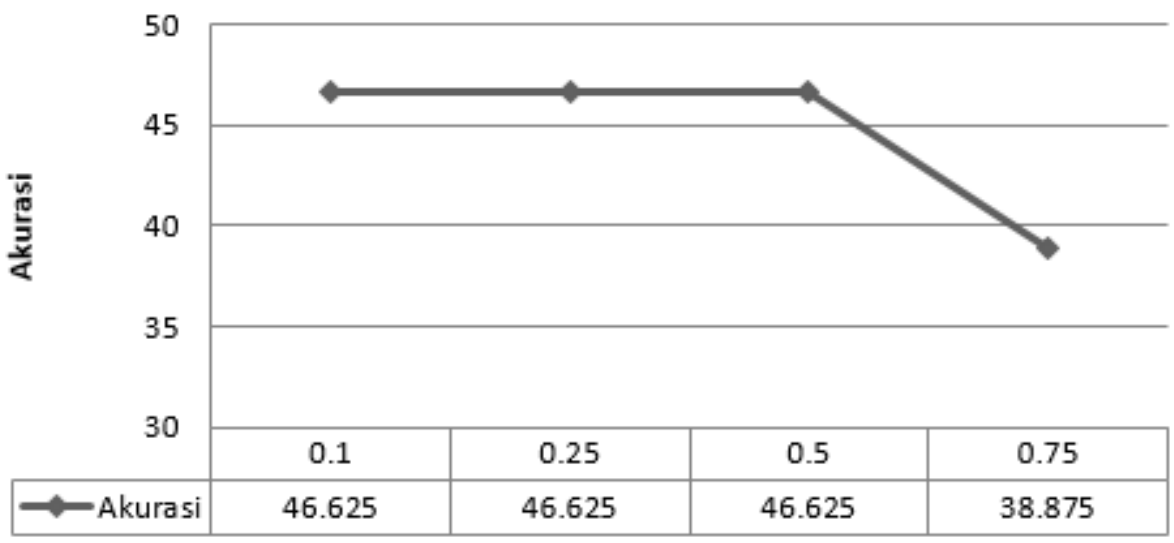

Gambar 3. Pengaruh learning rate terhadap akurasi

Dari percobaan yang dilakukan ukuran learning rate akan menentukan tingkat akurasi yang didapat, dimana semain kecil ukuran learning rate maka akurasi yang didapatkan akan semakin baik, meski pada nilai learning rate 0.5 akurasi tidak lagi berubah. Hal tersebut dikarenakan laju pembelajaran pada masing-masing iterasi akan dikontrol oleh learning rate yang ditentukan.

\subsection{Jumlah Hidden Layer}

Dilakukan pengujian jumlah hidden layer dengan masing-masing jumlah hidden layer memiliki jumlah node 30 dengan threshold rate 0.5 dan learning rate 0.1 . Selanjutnya dilakukan pengujian dengan jumlah hidden layer yang berbeda diantaranya 1 hidden layer, 2 hidden layer dan 3 hidden layer. Hasil perbandingan tersebut dapat dilihat pada Gambar 4. 


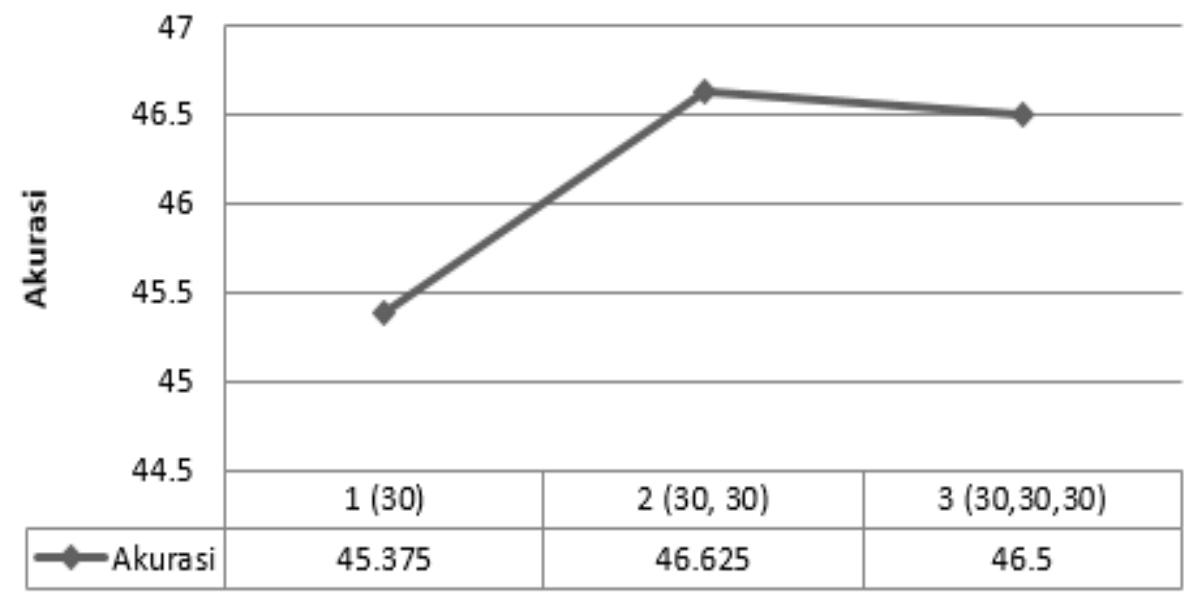

Gambar 4. Pengaruh jumlah hidden layer terhadap akurasi

Dari percobaan yang dilakukan untuk menguji pengaruh jumlah hidden layer terhadap akurasi, jumlah hidden layer akan bergantung pada jumlah input serta output pada model neural network yang dibuat, pada kasus ini input neural netowrk berjumlah 5 sedangkan jumlah outputnya 8, dan didapatkan jumlah hidden layer optimal pada kasus ini menggunakan 2 hidden layer. Terdapat penurunan akurasi ketika jumlah hidden layer meningkat dari 2 menjadi 3 hal tersebut disebabkan jumlah hidden layer yang optimal tergantung dengan dataset training yang diterapkan seperti yang dijelaskan pada penelitian [19].

\subsection{Jumlah Node Hidden Layer}

Dilakukan pengujian jumlah node pada hidden layer dengan hidden layer 2 dan ditetapkan threshold 0.5 dan learning rate 0.1 . Selanjutnya dilakukan pengujian dengan jumlah node pada hidden layer yang berbeda diantaranya 10 node, 20 node, 30 node, dan 40 node pada masing masing hidden layer. Hasil perbandingan tersebut dapat dilihat pada Gambar 5.

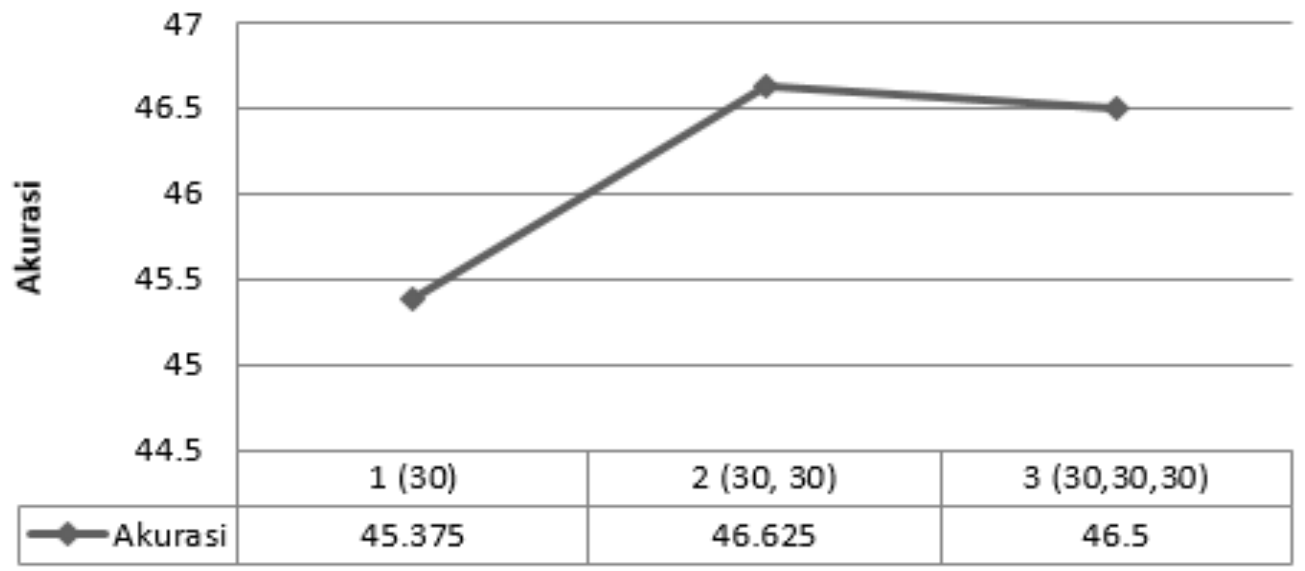

Gambar 5. Pengaruh jumlah node hidden layer terhadap akurasi

Dari percobaan yang dilakukan untuk menguji pengaruh jumlah node pada hidden layer terhadap akurasi didapatkan semakin banyak jumlah node pada hidden layer maka akurasi akan semakin bagus, hal ini disebabkan semakin banyak jumlah node pada hidden layer maka kemungkinan kombinasi input akan semakin banyak dan hasil klasifikasi yang didapat akan semakin bagus, namun semakin banyak jumlah node hidden layaer akan menyebabkan overfitting pada model 
yang dibuat, dan menyebabkan akurasi bagus pada proses training namun jelek pada proses testing dengan data yang berbeda dengan proses training sesuai dengan penelitian [21].

\subsection{Pengukuran Akurasi}

Dari hasil yang telah dilakukan sebelumnya maka dipilih konfigurasi dengan nilai learning rate yang kecil yakni 0.1 yang juga memiliki akurasi lebih bagus bila dibandingkan dengan nilai learning rate yang lain, serta jumlah hidden layer 2 dan jumlah node hidden layer 30 yang memiliki tingkat akurasi lebih bagus. Selanjutnya dilakukan proses klasifikasi pada model tersebut dengan menggunakan data berjumlah 9822 record yang telah dinormalisasi dengan input 5 yakni v1penghasilan, v2-biaya tempat tinggal, v3-tagihan listrik, v4-pajak motor dan v5- pajak mobil. Dari percobaan yang dilakukan didapatkan hasil sebagai berikut:

Sehingga didapatkan akurasi dari klasifikasi dengan model ini sebagai berikut:

$$
\text { Akurasi }=\frac{688}{800} \times 100 \%=86 \%
$$

Arsitektur model jaringan syaraf tiruan dengan akurasi terbaik ditunjukkan pada Gambar 6 .

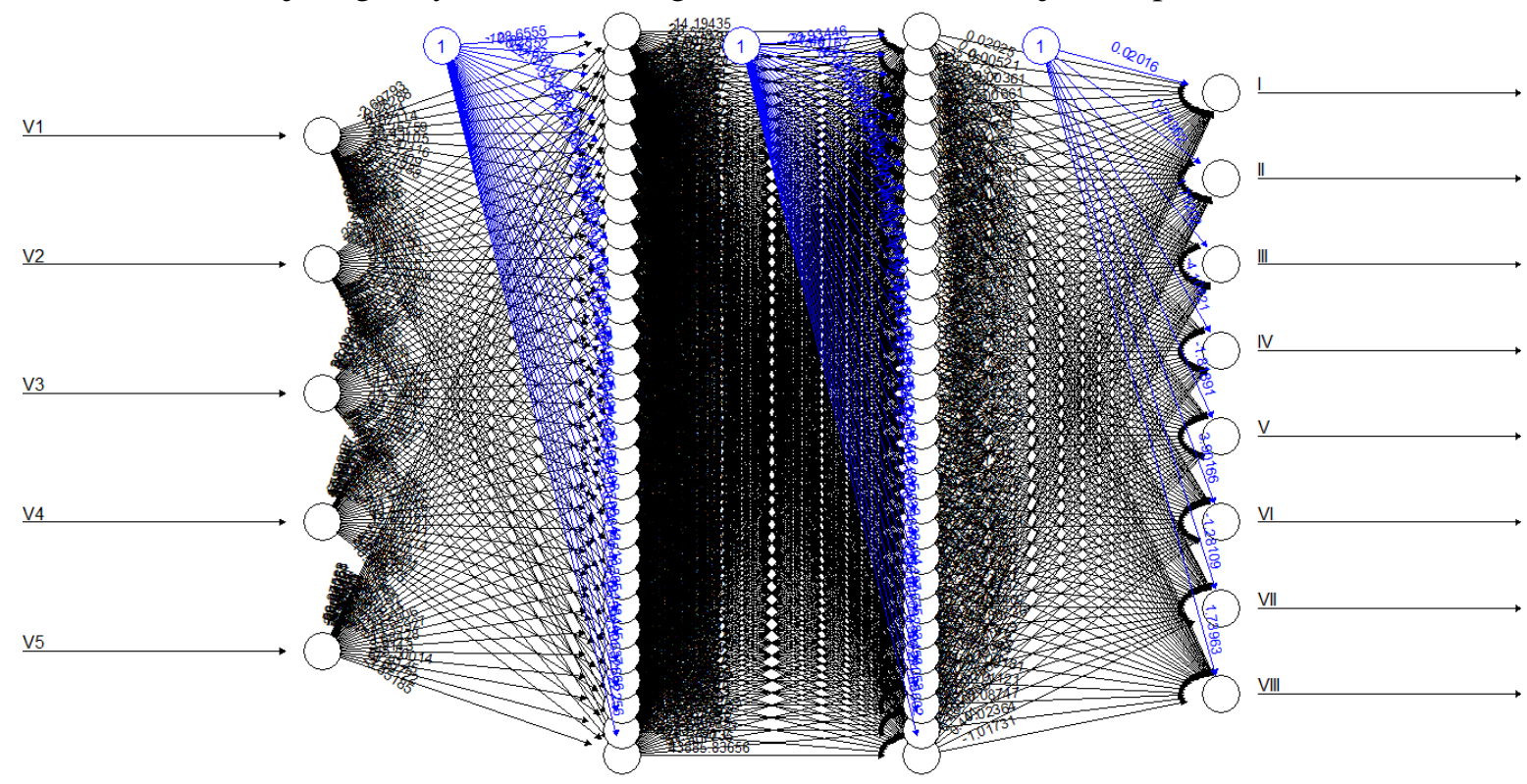

Gambar 6. Arsitektur model jaringan syaraf tiruan terbaik

Dapat dilihat bahwa proses pembelajaran yang dilakukan pada kasus uang kuliah tunggal untuk mahasiswa baru di Universitas XYZ dengan menggunakan backpropagation dengan akurasi klasifikasi sebesar $86 \%$. Hasil yang belum mencapai $90 \%$ tersebut bisa disebabkan oleh data yang masih terdapat banyak missing value dan proses sampling yang mungkin kurang optimal sehingga mempengaruhi akurasi model yang diperoleh.

\subsection{Implementasi Model}

Model terbaik yang diperoleh sebelumnya perlu dilakukan integrasi terlebih dahulu dari program R ke PHP, sehingga digunakan API sebagai jembatan penghubung kedua bahasa pemrograman yang berbeda [19]. Sistem yang dibuat dimaksudkan sebagai mekanisme interaksi antara mahasiswa baru dan PUSTIKOM Universitas XYZ selaku staff pengelola data UKT. Berikut 
tampilan dan proses pada sistem yang siap dioperasikan oleh PUSTIKOM Universitas XYZ untuk digunakan oleh mahasiswa ditunjukan pada Gambar 7.

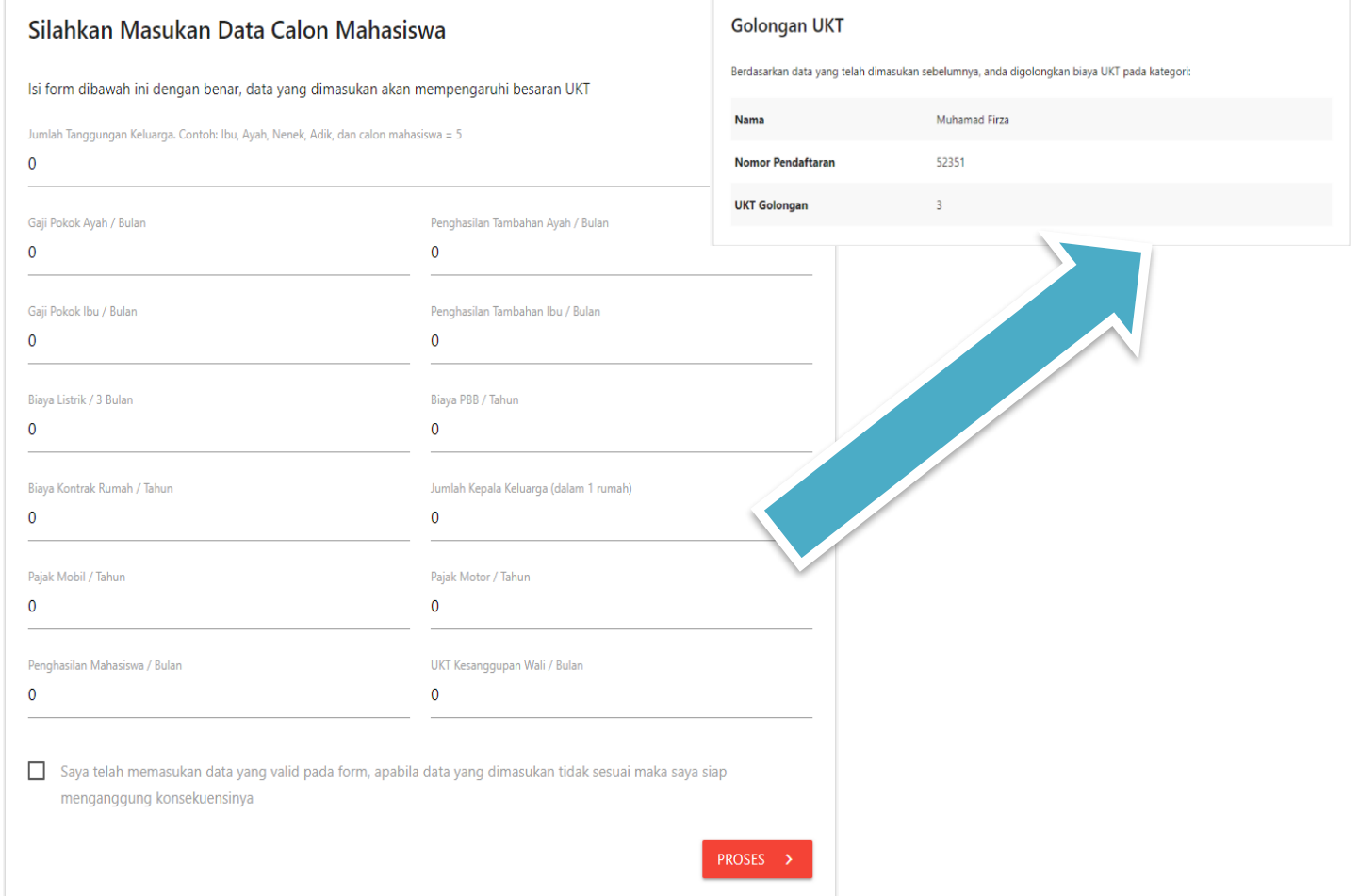

Gambar 7. Hasil penentuan golongan UKT

1. Langkah pertama pengguna (mahasiswa) harus login dengan menggunakan nomor pendaftaran ketika ujian dan tanggal lahir.

2. Langkah selanjutnya pengguna (mahasiswa) harus mengisi form yang akan digunakan dalam penentuan UKT.

3. Setelah pengguna (mahasiswa) mengisi dan menekan tombol proses, maka proses prediksi dengan menggunakan backrpopagation akan diproses. Selanjutnya input form dan golongan mahasiswa akan dimasukan ke database dan menampilkan hasil golongan UKT yang didapatkan oleh mahasiswa.

\section{KESIMPULAN DAN SARAN}

\subsection{Kesimpulan}

Berdasarkan pada hasil penelitian yang telah diperoleh, maka beberapa hal yang dapat ditarik menjadi kesimpulan diantaranya; Model terbaik sistem pendukung keputusan penentuan uang kuliah tunggal dengan menggunakan 5 variabel memiliki tingkat kepercayaan 86\%; Pada parameter learning rate disimpulkan bahwa semakin kecil nilai learning rate maka akurasi yang didapatkan akan semakin baik; Pada parameter jumlah hidden layer disimpulkan bahwa akan keefektifan jumlah hidden layer bergantung pada jumlah input serta output pada model neural network yang dibuat; Pada parameter jumlah node pada hidden layer disimpulkan bahwa semakin banyak jumlah node pada hidden layer maka akurasi akan semakin baik.

\subsection{Saran}

Berdasarkan kesimpulan yang telah dipaparkan, disarankan untuk penelitian selanjutnya dapat menggunakan cluster computing agar proses learning model lebih cepat dan pembuatan model 
dilakukan pada bahasa pemrograman yang implementatif pada sistem informasi website, sehingga tidak perlu diimplementasikan API sebagai jembatan penghubung bahasa pemrograman.

\section{DAFTAR PUSTAKA}

[1] R.Y. Dyah dan A. Marom, "Analisis Kebijakan Penyelenggaraan Pendidikan Berbasis Uang Kuliah Tunggal Bagi Perguruan Tinggi Negeri Fakultas Ilmu Sosial Dan Ilmu Politik Universitas Diponegoro Semarang Jawa Tengah", Journal of Public Policy and Management, vol. 6, no. 2, 2017.

[2 ]R. H. Sprague, H. J Watson, "Decision Support Systems: Putting Theory Into Practice", Englewood Cliffs, NJ: Prentice-Hall, 1986.

[3] S. Kisilevich, D. Keim dan L. Rokach, "A GIS-based Decision Support System for Hotel Room Rate Estimation and Temporal Price Prediction: The Hotel Brokers' Context", Elsivier, vol. 54, no.2, 2003.

[4] A. Phdungsilp, "Integrated energy and carbon modeling with a decision support system: Policy scenarios for low-carbon city development in Bangkok", Elsivier, vol.38, no.9, pp. 4808-4817, 2010.

[5] J. Xin dan M.J. Embrechets, "Supervised Learning with Spiking Neural Networks". IJCNN, vol. 1, 2011.

[6] N.M. Pinoriya dan S.N. Singh, "An Adaptive Wavelet Neural Network-Based Energy Price Forecasting in Electricity Market"s. IEEE Transactions on Power Systems, vol. 23, 2008.

[7] V. Limsombunchai, "House Price Prediction: Hedonic Price Model vs. Artificial Neural Network”. NZARES Conference, 2004.

[8] P. Mandal, T. Senjyu dan N.A. Urasaki, "Novel Approach to Forecast Electricity Price for PJM Using Neural Network and Similar Days Method”. IEEE Transactions on Power Systems, vol. 22, 2007.

[9] G. Tkacz, "Neural Network Forecasting of Canadian GDP Growth". Elsivier: International Journal of Forecasting, vol.17, 2001.

[10 ]J.Z. Wang, J.J. Wang, Z.G. Zhang, S.P. Guo, "Forecasting Stock Indices with Backpropagation Neural Network". Elsivier: Expert Systems with Applications, vol.38, issue 11, 2011.

[11] H. Taud dan J. Mas, "Multilayer Perceptron (MLP)", Springer: Geomatic Approaches for Modeling Land Change Scenarios, 2017.

[12] X. Yu, M.O. Efe dan O.A. Kaynak, "General Bbackpropagation Algorithm for Feedforward Neural Networks Learning". IEEE Transactions on Neural Networks, vol.13, issue 1, 2002.

[13] M.N. Siddique dan M.O. Tokhi, "Training Neural Networks: Backpropagation vs. Genetic Algorithms". IJCNN, vol.1,2001.

[14] G.R. Williams, "Learning Representations by Back-propagating Errors". Nature, no.323, pp.533-536, 1986.

[15] L Yoppi A, S. Latuconsina, E. R. Persulessy, “Aplikasi Jaringan Saraf Tiruan Backpropagation untuk Memprediksi Prestasi Siswa SMA (Studi kasus: Prediksi Prestasi Siswa SMAN 4 Ambon)," Jurnal Matematika Integratif., vol. 11, no. 2, 2015.

[16] A.L. Yoppi, S. Latuconsina dan E. R. Persulessy, "A Comparison of Classification Accuracy for Gender Using Neural Networks Multilayer Perceptron (MLP), Radial Basis Function (RBF) Procedures Compared to Discriminant Function Analysis and Logistic Regression Based on Nine Sports Psychological Constructs to Measure Motivations to Participate in 
Masters Sports Competing at the 2009 World Masters Games," International Symposiumon Computer Science in Sports (ISCSS)., vol. 392, no. 1, 2015.

[17] T. James, "Theoretical Analysis of an Alphabetic Confusion Matrix". Perception \& Psychophysics, vol.9, no.1, pp. 40-50, 1971.

[18] Juha, "The Statistical Basis of Laboratory Data Normalization". Drug information journal, pp. 101-107, 2003.

[19] Avery, “Adaptive Multi-protocol Communications System". U.S. Patent Application, no.10, 2002.

[20] W. Duch, T. Maszczyk, N. Jankowski, "Make it Cheap: Learning with O(nd) Complexity". IJCNN, pp. 132-135, 2012.

[21] Rich, Lawrance, Steve, Giles dan C. Lee, "Overfitting in Neural Nets: Backpropagation, Conjugate Gradient, and Early Stopping”, Neural Information Processing Systems, pp. 402408, 2001. 